Ekonomia - Wroclaw Economic Review 23/3 (2017)

Acta Universitatis Wratislaviensis

No 3807

DOI: 10.19195/2084-4093.23.3.4

\author{
Julitta Koćwin \\ Uniwersytet Wrocławski \\ Wydział Prawa, Administracji i Ekonomii \\ Instytut Nauk Ekonomicznych \\ jk.prawo.uni.wroc.pl@gmail.com
}

\title{
Zainteresowanie oraz opłacalność oszczędzania na emeryturę w III filarze
}

Artykuł nadesłany: 8 grudnia 2016 r.; artykuł zaakceptowany: 10 stycznia 2017 r.

JEL Classification: G2

Keywords: pension, pension funds, savings, III Pillar, bank deposits

\begin{abstract}
$^{*}$
Interest and profitability of saving for retirement in the Third Pillar

The problem presented in the research paper is the issue of retirement savings efficiency in the Third Pillar of social insurance in Poland. The object of accomplished analysis, which constitutes grounds for inference was "the number of accounts in the Third Pillar and the value of accumulated funds", which allowed defining "interest and attractiveness of the use of financial products offered by the Third Pillar" and "profitability of saving in the Third Pillar". The results of the research, which determine present interest in saving in the Third Pillar confirm that additional forms of pension security have not reached the desired by the government level of development. Market growth will not occur unless there are financial incentives. Common concerns rouse the role of the state in the Third Pillar, and especially the possibility of taking over accumulated savings by government, as was done with savings accumulated in the Second Pillar (OFE). In this situation, choosing a product of the Third Pillar is a less meaningful issue. It is more important to regularly save money in order to be able to gain from the so called 'compound interest', also choosing the right investment strategy and attitude towards risk.
\end{abstract}

* Serdeczne podziękowania dla pani mgr Justyny Ziobrowskiej za pomoc w thumaczeniu streszczenia. 


\section{Wstęp}

Aktualnie problem zabezpieczenia emerytalnego poruszany jest dość często przez polityków, a tematyka ta obecna jest w mediach, starających się zarówno zwrócić uwagę opinii publicznej na kwestie związane z wysokością przyszłych świadczeń emerytalnych oraz koniecznością uzupełnienia obowiązkowego systemu emerytalnego o dodatkowe środki pochodzące z indywidualnych oszczędności, jak i zainteresowanie społeczeństwa oszczędzaniem w III filarze.

Niestety nie obserwuje się większego zainteresowania opinii publicznej tym problemem mimo informowania społeczeństwa o niedostatecznej wysokości przyszłych świadczeń emerytalnych, niekorzystnych prognozach demograficznych, które w przyszłości doprowadzą do nierównego stosunku osób płacących składki do liczby świadczeniobiorców, a także stopniowego odchodzenia od zdywersyfikowanego systemu źródeł wypłaty świadczeń.

Celem artykułu jest zwrócenie uwagi na kwestię, że dodatkowe formy zabezpieczenia emerytalnego nie osiągnęły do tej pory pożądanego przez rząd poziomu rozwoju. Bez zachęt o charakterze fiskalnym nie nastąpi wzrost tego rynku, o czym świadczy obecne zainteresowanie oszczędzaniem w III filarze.

\section{Liczba kont w III filarze oraz wysokość zgromadzonych środków}

W 1999 roku wprowadzono kapitałowo-repartycyjny system emerytalny składający się z tak zwanych trzech filarów, mający zapewnić dywersyfikację ryzyka i solidną emeryturę. I filar stanowi Fundusz Ubezpieczeń Społecznych (FUS) zarządzany przez ZUS, do którego każdy ubezpieczony wpłaca $12,22 \%$ pensji brutto. Od 1 maja 2011 roku do ZUS przekazywane jest dodatkowo 5\% pensji brutto ubezpieczonego (pomniejszona składka z II filaru). Pieniądze na kontach w FUS stanowią zobowiązanie państwa do wypłaty emerytury po zakończeniu aktywności zawodowej pracownika. Należy jednak wziąć pod uwagę, że bez względu na to, ile kto zarabia, przyszła emerytura podlega waloryzacji w wysokości uznaniowej, która zależy od polityki rządu (Dygas 2014, s. 32).

Reforma emerytalna z 1999 roku poza FUS wprowadziła obowiązkowy II filar - Otwarte Fundusze Emerytalne (OFE). Do OFE przekazywano 7,30\% pensji ubezpieczonych, potem $2,30 \%$, a zgodnie z ustawą z 6 grudnia 2013 roku — 2,92\% (Ustawa 2013). Reforma miała być szansą na wyższą emeryturę dzięki inwestowaniu ponad 7\% składki w instrumenty finansowe. Z OFE miało pochodzić około jednej trzeciej przyszłej emerytury, a więc niemalże tyle samo, co z dwukrotnie wyższej składki przekazywanej do FUS. Niestety rząd dwukrotnie zabrał te oszczędności. W 2011 roku zagarnięto dużą część składki z OFE, a w 2013 roku — ponad połowę oszczędności. Od 3 lutego 2014 roku (zgodnie 
z decyzją rządu premiera Donalda Tuska i parlamentu RP) wytransferowano z kapitałowej części systemu emerytalnego do ZUS 153,15 mld zł. Każdemu ubezpieczonemu zabrano 51,50\% jego oszczędności emerytalnych. Decyzje te doprowadziły do upadku II filaru systemu emerytalnego. Do końca 2013 roku przeszło 16,37 mln uczestników funduszy emerytalnych odłożyło na swoich kontach ponad 300 mld zł. W tym samym czasie w III filarze zgromadzono łącznie aktywa w wysokości 13,8 mld zł (Dygas 2014, s. 32).

III Filar ma charakter dobrowolnego ubezpieczenia emerytalnego i stanowi uzupełnienie filaru I i II. Został utworzony w odpowiedzi na prognozy mniejszych emerytur w przyszłości. Zakładano, że ze względu na te przewidywania duża część społeczeństwa będzie dobrowolnie oszczędzać w III filarze emerytalnym. Jednak lokowanie kapitału w III filarze nie jest popularne. Również wysokość zgromadzonych tam środków nie jest wystarczająco wysoka, by zwiększyć przyszłe emerytury.

$\mathrm{Na}$ III filar składają się różne formy oszczędzania. Obok formy grupowego oszczędzania na emeryturę w Pracowniczych Programach Emerytalnych (PPE) (Ustawa 1997) występują dwie inne: Indywidualne Konto Emerytalne (IKE) oraz Indywidualne Konto Zabezpieczenia Emerytalnego (IKZE) (Ustawa 2004), wsparte zachętami podatkowymi. Na wysokość przyszłej emerytury mają też wpływ indywidualne, dobrowolne formy oszczędzania kapitału, takie jak prywatne oszczędności, mające w przyszłości uzupełnić świadczenia emerytalne z pozostałych dwu filarów. W tabeli 1 przedstawiono dane dotyczące liczby kont w III filarze oraz zgromadzonych na nich środków.

W roku 2013 we wszystkich instytucjach III filaru wzrosła wartość zgromadzonych środków (w PPE o 13\%, w IKE o 21\%, w IKZE o 125\% — choć wartość zgromadzonych w IKZE środków jest nieznaczna i wynosi ok. $119 \mathrm{mln}$ zł). W dużej części (poza IKZE) wzrost ten był wypracowany przez działalność inwestycyjną, a nie przez wpływ nowych składek (UKNF 2014b, s. 29).

Na koniec 2015 roku IKE dysponowało 858,7 tys. osób (w 2014 - 824,5 tys. osób, w 2013 - 817,7 tys. osób), to jest 5,3\% liczby osób pracujących (w 2014 - 5,1\%), na których kontach zgromadzono aktywa o wartości 5,7 mld zł (wzrost w skali roku o 13\%), podczas gdy w 2014 było to 5 mld zł (wzrost w skali roku o 17,8\%). Z kolei na IKZE oszczędzało 597,6 tys. (w $2014-528,1$ tys. osób), co stanowiło 3,7\% liczby osób pracujących (w 2014 - 3,3\%), którym udało się zgromadzić 0,6 mld zł (622 mln zł) aktywów (w 2014 - 295,4 mln zł), co oznacza wzrost o $110,6 \%$ w porównaniu do 2014 roku.

Wskaźnik liczby IKE zasilanych wpłatami do ogółu funkcjonujących IKE zmniejszył się i wyniósł 31,4\% (w 2014 - 32\%, w 2013 - 31,8\%), średnia wpłata wyniosła 3,5 tys. zł - wzrost o 0,1 tys. zł (w 2014 r. średnia wpłata na IKE wyniosła 3,4 tys. zł - wzrost o 0,3 tys. zł), jednakże najwyższą wartość średniej wpłaty zauważono u podmiotów prowadzących działalność maklerską: 8,7 tys. zł (w $2014-8,6$ tys. zł, w $2013-8,8$ tys. zł). Analogiczny wskaźnik dla 
IKZE wyniósł $23,9 \%$ (w $2014-16,4 \%$ ), a średnia wpłata - 2,6 tys. zł (wzrost o 0,3 tys. zł). Ponadto w roku 2015 po raz pierwszy od momentu powstania IKZE otwarto więcej IKE (utworzono 72,8 tys. nowych IKE — o 17,1 tys. więcej) i IKZE (powstało 92,2 tys. IKZE - o 28,7 tys. kont więcej) w porównaniu do roku poprzedniego (UKNF 2016a, s. 3-4; UKNF 2015, s. 3-4).

Tabela 1. Liczba kont i programów oraz wartość zgromadzonych na nich środków

\begin{tabular}{|c|c|c|c|}
\hline & IKE & IKZE & PPE \\
\hline & \multicolumn{3}{|c|}{ Dane na koniec 2011 roku } \\
\hline Liczba kont i programów & 814449 & - & 1116,0 \\
\hline \multirow[t]{2}{*}{ Wartość środków } & 2763980 & - & 6597,7 \\
\hline & \multicolumn{3}{|c|}{ Dane na koniec 2012 roku } \\
\hline Liczba kont i programów & 813292 & 496821 & 1094,0 \\
\hline \multirow[t]{2}{*}{ Wartość środków (w zł) } & 3530313 & 52882 & $8350,9 \mathrm{mln}$ \\
\hline & \multicolumn{3}{|c|}{ Dane na koniec 2013 roku } \\
\hline Liczba kont i programów & 817651 & 496426 & 1070,0 \\
\hline \multirow[t]{2}{*}{ Wartość środków (w zł) } & 4271150 & 119206 & $9407,3 \mathrm{mln}$ \\
\hline & \multicolumn{3}{|c|}{ Dane na koniec 2014 roku } \\
\hline Liczba kont i programów & 824485 & 528142 & 1064,0 \\
\hline \multirow[t]{2}{*}{ Wartość środków (w zł) } & 5030537 & 295350 & 10259,5 \\
\hline & \multicolumn{3}{|c|}{ Dane na koniec 2015 roku } \\
\hline Liczba kont i programów & 858725 & 597560 & 1054,0 \\
\hline Wartość środków (w zł) & 5682699 & 621968 & 10623,4 \\
\hline
\end{tabular}

Źródło: UKNF 2016a, s. 10, 21; UKNF 2016b, s. 6-7; UKNF 2015, s. 10, 21; UKNF 2014a, s. 9-10, 20-21; UKNF 2013, s. 9, 11.

Według stanu na dzień 31 grudnia 2015 r. w III filarze zgromadzono łącznie 16,9 mld zł, z czego dwie trzecie środków w PPE, prawie jedną trzecią na IKE, natomiast na IKZE — ledwie 3\% oszczędności. Liczba osób posiadających oszczędności w III filarze wynosi $1,8 \mathrm{mln}$, jednakże do każdej z tych instytucji tylko część uczestników wnosi systematycznie środki na konto. W 2015 roku zasilono wpłatami jedynie co trzecie IKE i co czwarte IKZE, co oznacza, że z całkowitej liczby 1,4 mln oszczędzających na IKE i IKZE zaledwie 412 tys. osób dokonało w 2015 roku jakichkolwiek wpłat na konta emerytalne. Z kolei w PPE, według stanu na 31 grudnia 2015 r., z ogólnej liczby 393 tys. uczestników 62,9 tys. osób (16\%) stanowili uczestnicy bierni. W 2015 roku wpłaty emerytalne w ramach III filaru dokonane zostały na konta 742 tys. osób. Biorąc pod uwagę, że w Polsce liczba osób pracujących na koniec IV kwartału 2015 roku wynosiła $16276 \mathrm{mln}$ osób (według GUS), oznacza to, że ledwie co 23 osoba pracująca dokonała w rzeczonym roku jakiekolwiek dodatkowej wpłaty na poczet przyszłej emerytury. 
Jeżeli weźmiemy pod uwagę ostatnie 5 lat, okaże się, że aktywa PPE pomiędzy rokiem 2011 a 2015 prawie się podwoiły i po takim czasie wyniosły $10,6 \mathrm{mld}$ zł. W latach 2011-2015 w PPE przybyło bowiem blisko 50 tys. uczestników. Corocznie do PPE wpływają składki, których wartość wynosi ok. 1 mld zł. Jednak biorąc pod uwagę prognozy demograficzne, tempo akumulacji tych oszczędności nie jest zadowalające. Ponadto w 2015 roku trudno doszukać się jakichkolwiek symptomów ożywienia na tym rynku. Poszczególne parametry oceniające go wypadają niekorzystnie w porównaniu do notowanych jakiś czas temu, na przykład niższy niż w ostatnich latach przyrost wartości aktywów (o $364 \mathrm{mln}$ zł — w porównaniu do ostatnich lat wartość aktywów wzrastała rocznie o kwoty rzędu $1 \mathrm{mld}$ zł, w 2012 roku było to nawet 1,7 mld zł). Za sytuację na rynku PPE w 2015 roku odpowiadają czynniki o charakterze zewnętrznym, takie jak wyjątkowo niskie stopy procentowe, załamanie cen surowców, uwolnienie kursu franka szwajcarskiego, obawy o rozpad strefy euro czy spowolniony wzrost gospodarczy w Chinach. Wszystkie te czynniki destabilizowały te rynki oraz wywarły na nie negatywny wpływ, co odbiło się na wynikach inwestycyjnych oraz niskim przyroście aktywów netto PPE (część wpłat została „skonsumowana” przez ujemne stopy zwrotu, w wyniku czego roczny przyrost aktywów netto jest mniejszy niż suma wpłat wniesionych w ciągu roku do programów) (UKNF 2016b, s. 29).

Także poprzednie lata nie przyniosły oczekiwanego i pożądanego stopnia rozwoju PPE. Obserwując ich rozwój, można stwierdzić, że instytucja ta wyczerpała swój potencjał wzrostu, w związku z czym rozwój programów dokonuje się systematycznie, lecz za mało dynamicznie. $Z$ kolei wprowadzenie zmian $\mathrm{w}$ tej instytucji może spowodować u dotychczasowych uczestników programów całkowitą utratę zaufania do idei gromadzenia oszczędności emerytalnych, która po raz pierwszy została już naruszona po dokonaniu zmian w II filarze systemu emerytalnego (UKNF 2016b, s. 30).

W 2013 roku udziały na rynku PPE były przejmowane przez fundusze inwestycyjne, na tym rynku traciły natomiast zakłady ubezpieczeń na życie. Formę ubezpieczeniową w ostatnich latach dotyka recesja, o czym świadczy największy wskaźnik likwidowanych programów, mała liczba nowych programów, a także spadek liczby uczestników. Większe zainteresowanie funduszami inwestycyjnymi w 2013 roku może być związane z tym, że obniżyły one w umowach funkcjonujących programów stawki kosztów pobieranych z aktywów funduszy (UKNF 2014b, s. 30).

Za istotne zjawiska na rynku PPE w 2015 roku należy uznać:

— utrzymujące się od 2012 rok do roku obniżenie się liczby działających programów, niepoparte spadkiem liczby uczestników i wartości aktywów;

- ponowne zwolnienie tempa wzrostu istotnych parametrów rynku PPE w zestawieniu z rokiem 2014 (wartość zgromadzonych aktywów, wartość odprowadzonych składek, liczba rejestrowanych programów) (UKNF 2016b, s. 3). 
Rozwój PPE, w których sponsorem składki jest pracodawca, zależy nie tylko od woli pracodawców i pracowników, lecz także od możliwości sfinansowania składek przez przedsiębiorców, a także uwarunkowane jest otoczeniem makroekonomicznym (wzrost gospodarczy, popyt, inwestycje), w jakim funkcjonują przedsiębiorstwa. W wypadku spadku tempa wzrostu gospodarczego (spadku popytu i inwestycji) przedsiębiorcy nie będą zaciągać długoterminowych zobowiązań i nie będą uruchamiać programu PPE (UKNF 2014b, s. 29).

Na podstawie przedstawionych danych statystycznych można stwierdzić, że PPE nie ma większego znaczenia - obserwuje się stagnację tego produktu emerytalnego oraz spadek większości wskaźników.

W tabeli 2 przedstawiono natomiast liczbę kont IKZE i IKE z podziałem na oferujące je instytucje finansowe. Na podstawie zaprezentowanych danych można stwierdzić, że oszczędzanie w ramach III filaru nie cieszy się zainteresowaniem. Zgodnie z założeniami reformy z 1999 roku ubezpieczeni mieli z niego otrzymać około 30\% całkowitego świadczenia. Wprowadzony w 2012 roku nowy produkt - IKZE - również został uznany za mało atrakcyjny.

W 2015 roku 92,2 tys. osób założyło IKZE, było to o 28,7 tys. więcej niż w 2014 (w 2014 - 63,5 tys. osób, mniej o 1,8 tys. niż w 2013). Najwięcej aktywów IKZE posiadały firmy ubezpieczeniowe: $281,9 \mathrm{mln}$ zł (w 2014 — 167,7 mln zł). Najwięcej IKZE zostało założonych w funduszach inwestycyjnych - 38,1 tys. kont (w 2014 roku miało to miejsce w przypadku zakładów ubezpieczeń — 34 tys. kont), a najmniej w podmiotach prowadzących działalność maklerską - 1,6 tys. kont (w 2014 - 1,8 tys. kont) (UKNF 2016a, s. 4; UKNF 2015, s. 4).

We wszystkich grupach wiekowych z wyjątkiem osób w wieku do 30 lat jest więcej IKE niż IKZE (razem o 43,7\% więcej IKE niż IKZE). Wśród osób w wieku do 30 lat jest niemalże 2,5-krotnie więcej kont IKZE niż IKE (68,7 tys. IKZE i 28,5 tys. IKE) (UKNF 2016a, s. 4).

Tabela 2. Liczba kont w poszczególnych instytucjach w latach 2012-2014

\begin{tabular}{c|c|c|c|c|c|r|r}
\cline { 2 - 8 } & Rok & Razem & $\begin{array}{c}\text { Zakłady } \\
\text { ubezpie- } \\
\text { czeń }\end{array}$ & $\begin{array}{c}\text { Towarzystwa } \\
\text { Funduszy } \\
\text { Inwestycyjnych }\end{array}$ & $\begin{array}{c}\text { Podmioty } \\
\text { prowadzące } \\
\text { działalność } \\
\text { maklerską }\end{array}$ & Banki & $\begin{array}{c}\text { Dobrowolne } \\
\text { Fundusze } \\
\text { Emerytalne }\end{array}$ \\
\hline \multirow{4}{*}{$\begin{array}{c}\text { Liczba } \\
\text { kont }\end{array}$} & 2012 & 496821 & 363399 & 5202 & 559 & 19 & 127642 \\
\cline { 2 - 9 } IKZE & 2013 & 496426 & 388699 & 9565 & 1012 & 33 & 97117 \\
\cline { 2 - 9 } & 2014 & 528142 & 418935 & 17510 & 2797 & 8105 & 80795 \\
\hline \multirow{3}{*}{$\begin{array}{c}\text { Liczba } \\
\text { kont }\end{array}$} & 2015 & 597560 & 442735 & 54471 & 4325 & 13735 & 82294 \\
\cline { 2 - 8 } IKE & 2013 & 813292 & 557595 & 188102 & 20079 & 47037 & 479 \\
\cline { 2 - 8 } & 2014 & 824485 & 573515 & 174515 & 22884 & 51625 & 1946 \\
\hline & 2015 & 858725 & 573092 & 205494 & 25220 & 52371 & 2548 \\
\hline
\end{tabular}

Źródło: UKNF 2016a, s. 9, 20; UKNF 2015, s. 9, 20; UKNF 2014a, s. 9, 20. 
W 2015 roku tylko zakłady ubezpieczeń odnotowały spadek liczby IKE, na które wpłacano składki, a także zmniejszenie kwoty wpłacanych składek, w porównaniu do roku 2014. Mimo to zakłady ubezpieczeń zgromadziły najwięcej aktywów IKE: 2,1 mld zł (podobnie jak w 2014 - 1,9 mld zł). Utworzono 72,8 tys. nowych IKE, o 17,1 tys. więcej niż w 2014 roku (w $2014-55,7$ tys., o 2,2 tys. mniej niż w 2013). Najwięcej IKE założono w towarzystwach funduszy inwestycyjnych — 44,4 tys. kont (w 2014 roku w zakładach ubezpieczeń — 31 tys. kont), a najmniej $\mathrm{w}$ dobrowolnych funduszach emerytalnych $-0,6$ tys. kont (w 2014 - 0,5 tys. kont). Jednocześnie 29,4 tys. osób zlikwidowało rachunki IKE z całkowitym zwrotem środków — spadek o $21 \%$ (w 2014 - 37,3 tys., co oznacza spadek o 12,8\%). Najwięcej rachunków IKE zamknięto w zakładach ubezpieczeń - 15,4 tys. osób (w 2014 - w funduszach inwestycyjnych - 17,1 tys. osób). Wypłatę środków z IKE zainkasowało 8,5 tys. osób (wzrost o 10\%), z czego najwięcej w funduszach inwestycyjnych $-3,8$ tys. osób i zakładach ubezpieczeń — 3,6 tys. osób (w 2014 roku wypłatę zainkasowało 7,7 tys. osób — wzrost o 6,8\%, najwięcej także w funduszach inwestycyjnych $-3,8$ tys. osób).

W 2015 roku wpłaty środków pieniężnych do IKE wyniosły 1126,2 mln zł (wzrost o 28,5 mln zł, w 2014 roku wynosiły 1097,7 $\mathrm{mln}$ zł — wzrost o 113,8 $\mathrm{mln}$ zł), natomiast wypływy środków pieniężnych z IKE osiągnęły wartość 403,5 mln zł (wzrost o 13,4 mln zł, w 2014 roku — $390 \mathrm{mln}$ zł — wzrost o $23 \mathrm{mln}$ zł) (UKNF 2016a, s. 3, 25; UKNF 2015, s. 3).

Ekspertyzy, badania i ankiety potwierdzają, że wzrost dobrowolnego oszczędzania na emeryturę jest uzależniony od realnych zachęt podatkowych. Jeśli rząd chce zachęcić społeczeństwo do dobrowolnego oszczędzania, powinien całkowicie znieść opodatkowanie oszczędności gromadzonych w III filarze.

Wprowadzone w 2004 roku IKE, w przeciwieństwie do PPE, dało możliwość zwolnienia z podatku od zysków kapitałowych dochodu odkładanego na emeryturę. Ze względu na małe i stale zmniejszające się zainteresowanie IKE w 2008 roku wprowadzono zmiany legislacyjne, stwarzając możliwość wycofania części środków zgromadzonych na IKE, a także podwyższono kwoty limitu wpłat na IKE. Zmiany te nie spowodowały jednak wzrostu zainteresowania tą formą oszczędzania. Liczba osób oszczędzających w ramach IKE od początku jego funkcjonowania nigdy nie przekroczyła $6 \%$ liczby osób pracujących.

W związku z tym 1 stycznia 2012 roku rząd podwyższył wiek emerytalny oraz wprowadzono nowy produkt — IKZE. Aktualnie istnieje możliwość jednoczesnego posiadania IKE i IKZE.

Oszczędzanie w ramach IKE i IKZE nie cieszy się dużym zainteresowaniem głównie ze względu na dodatkowe obciążenia podatkowe. Tezę tę potwierdziły badania przeprowadzone przez CBOS w 2013 roku zatytułowane „Polacy a ulga podatkowa na IKZE". Zgodnie z ich wynikami przy $19 \%$ skali podatkowej inwestowanie w IKZE deklarowało $23 \%$ badanych, przy $10 \%$ podatku $-35 \%$, natomiast całkowite zniesienie opodatkowania oszczędności w ramach IKZE zachęciłoby do oszczędzania ponad połowę Polaków (IZFIA 2013, s. 2). 
$\mathrm{Z}$ uwagi na niewielkie zainteresowanie oszczędzaniem $\mathrm{w}$ ramach IKZE 15 stycznia 2014 roku, aby je upowszechnić i zwiększyć jego atrakcyjność, wprowadzono dodatkowe zmiany w IKZE (Ustawa 2013). Do zawierania umów o prowadzenie IKZE zachęcano poprzez:

— upraszczanie reguł związanych z określeniem wysokości maksymalnej rocznej wpłaty na IKZE, ustalając roczny limit wpłat na IKZE na 1,2-krotność prognozowanego na dany rok przeciętnego miesięcznego wynagrodzenia $\mathrm{w}$ gospodarce narodowej, zdefiniowanego w ustawie budżetowej. W kolejnym roku limit ten nie może być niższy niż limit wpłat na IKZE w roku poprzednim. Kwota maksymalnego limitu uzależniona jest od tempa wzrostu wynagrodzeń w Polsce i może się zmieniać w kolejnych latach;

- wprowadzenie opodatkowania wypłat z IKZE (także na rzecz osób uprawnionych) 10-procentowym zryczałtowanym podatkiem dochodowym zamiast opodatkowania według skali podatkowej, obowiązującego w momencie wypłaty. Opodatkowanie zwrotu środków z IKZE pozostało bez zmian - PIT według skali podatkowej.

Dokonane zmiany odnośnie do IKZE nie przyczyniły się jednak do zwiększenia liczby otwieranych kont emerytalnych (UKNF 2015, s. 25-26; III filar 2016).

Zastąpienie opodatkowania wypłaty z IKZE według skali PIT zryczałtowanym podatkiem dochodowym miało zachęcić do tej formy oszczędzania. Celem wprowadzonej zmiany miało być zmniejszenie obciążeń fiskalnych pod koniec oszczędzania na IKZE oraz korekta elementu niepewności co do wysokości podatku, który będzie trzeba zapłacić w przyszłości, przy wypłacie środków z IKZE. W opinii Ministerstwa Finansów dokonane modyfikacje miały przyczynić się do wzrostu popularności tej formy oszczędzania na cele emerytalne. Zdaniem ekspertów po zmianach wprowadzonych ustawą z 6 grudnia 2013 roku IKZE mogą konkurować z IKE. Jednak nawet po nich IKZE nadal nie cieszą się zainteresowaniem ze względu na małe możliwości finansowe większości społeczeństwa.

Powodów małego zainteresowania ofertą kont emerytalnych z III filaru, to jest IKE i IKZE, można upatrywać między innymi w tym, że:

- większość gospodarstw domowych nie ma nawyku długoterminowego oszczędzania. W sytuacji braku przymusu przeznaczania części dochodu na emeryturę, cały dochód pokrywa konsumpcję bieżącą;

— niskie dochody uniemożliwiają odkładanie i lokowania nadwyżek finansowych na emeryturę;

- istnieje przekonanie, że to państwo jest odpowiedzialne za dochody emerytalne przyszłych emerytów (UKNF 2015, s. 26). 


\section{Zainteresowanie i atrakcyjność korzystania z produktów finansowych oferowanych przez III filar}

Problem konieczności indywidualnego zapewniania przez społeczeństwo dodatkowych środków na przyszłą emeryturę jest systematycznie podnoszony przez rząd i media. Jednak działania te nic nie dają.

Głównymi czynnikami wpływającymi na konieczność przeprowadzania reformy w krajowym systemie emerytalnym są przyczyny demograficzne, to jest starzenie się społeczeństwa, wydłużająca się średnia długość życia oraz malejący wskaźnik urodzeń. Jednakże pomimo ciągłych ostrzeżeń, że przyszłe emerytury będą dużo niższe i nie zapewnią minimum egzystencji, oszczędzanie w III filarze nie cieszy się zainteresowaniem. Najistotniejszym powodem istniejącej sytuacji są ograniczone możliwości finansowe społeczeństwa, choć nie jest to jedyny powód. Produkty oferowane w III filarze należą do niszowych ze względu na ich nieprzewidywalność i niekorzystne warunki umowy, również związana z nimi ulga podatkowa nadal nie jest opłacalna, w związku z czym obywatele preferują gromadzenie oszczędności na emeryturę za pośrednictwem produktów bankowych.

\subsection{Atrakcyjność oszczędzania w III filarze w świetle badań}

Mimo coraz częstszej dyskusji na temat wysokości i szacunkowo niskich przyszłych emerytur wśród większości respondentów najczęściej wymienianym sposobem zapewniania sobie środków na życie na emeryturze (we wszystkich grupach społecznych z wyjątkiem osób prowadzących własną działalność gospodarczą) jest korzystanie z emerytury wypłacanej w oparciu o obowiązkowe składki, a w wypadku połowy tej grupy — jedynym, który biorą pod uwagę (CBOS 2012, s. 6).

$\mathrm{Z}$ badań wynika również, że indywidualne oszczędzanie na emeryturę zależy od poziomu zamożności respondentów. Osoby, które deklarowały oszczędzanie jako najskuteczniejszy sposób na zapewnienie sobie środków na życie po osiągnięciu ustawowego wieku emerytalnego, najczęściej wskazywały odkładanie pieniędzy w bankach ( $45 \%$, co stanowi $15 \%$ wszystkich badanych).

$\mathrm{Na}$ banki wskazywano ogólnie lub wymieniano konkretne produkty, z których najpopularniejsze są terminowe lokaty bankowe. Niewiele osób $(11 \%$ z tej grupy, co stanowi 4\% ogółu) wymieniało produkty inwestycyjne lub specjalne produkty służące gromadzeniu pieniędzy na emeryturę (III filar) (CBOS 2012, s. 4). Może to świadczyć o małym poziomie wiedzy oraz informowania respondentów o dostępnych na rynku produktach umożliwiających samodzielne oszczędzanie na emeryturę, a także o dużym zaufaniu do banków.

Wśród ankietowanych dominuje przeświadczenie, że sytuacja materialna po przejściu na emeryturę samoistnie się ustabilizuje (,jakoś to będzie”), pomimo że $84 \%$ badanych twierdzi, że państwo nie jest w stanie zabezpieczyć przyszłych świadczeń. Zmianie sytuacji nie sprzyja ciągle wysoki odsetek osób nieufających 
instytucjom finansowym w ogóle, jedna czwarta badanych nie powierzyłaby swoich oszczędności żadnej z nich. Największym zaufaniem w opinii ponad połowy Polaków cieszą się banki. Interesujące jest, że w wypadku osób, które deklarują systematyczne oszczędzanie na emeryturę, motywacja do oszczędzania jest identyczna - perspektywa niskiego świadczenia z ZUS i OFE (PWC 2013, s. 20).

Wyniki badań przeprowadzonych przez PWC wykazały, że respondenci mają świadomość konieczności dodatkowego oszczędzania na emeryturę, lecz w praktyce niewielu z nich to robi. Kwestia nadprogramowego odkładania środków na emeryturę jest istotna dla większości ankietowanych, jednak — jak potwierdzają ankiety — deklaracje rozmijają się z realiami życia codziennego. Pomimo że $74 \%$ badanych uważa za konieczne inwestowanie nadwyżek finansowych w celu zabezpieczenia swojej przyszłości na emeryturze, to jednak nieco więcej niż jedna trzecia $\mathrm{z}$ nich jest skłonna robić to w rzeczywistości. Tylko $13 \%$ badanych zamierza oszczędzać za pośrednictwem produktów z III filaru ubezpieczeń społecznych. Według przyszłych emerytów podstawowym źródłem środków na życie będą świadczenia wypłacane przez ZUS, KRUS i OFE. Wśród osób inwestujących nadwyżki finansowe dominującym motywem do oszczędzania jest prognozowana niska wysokość świadczeń emerytalnych.

Należy zaznaczyć, że wśród osób nieplanujących oszczędzać głównymi powodami nieinwestowania dodatkowych środków w celu zwiększenia przyszłych świadczeń emerytalnych jest brak nadwyżek finansowych oraz odkładanie tematu w czasie (PWC 2013, s. 22).

Wyniki badań przeprowadzonych w latach 2010-2014 wskazują, że rzeczywistość jest odmiennie postrzegana przez społeczeństwo, instytucje finansowe oraz ekspertów rynku. Przekazywane informacje nie mają istotnego wpływu na zwiększenie inwestowania środków na dodatkową emeryturę, na przykład za pośrednictwem III filaru ubezpieczeń społecznych. Wniosek ten potwierdzają wyniki badania CBOS z 2013 roku, zgodnie z którymi aż 81\% społeczeństwa oświadcza, iż nie zamierza oszczędzać na emeryturę za pośrednictwem dostępnych na rynku produktów emerytalnych (w tym PSO - Programów Systematycznego Oszczędzania) (PWC 2013, s. 12-13). Zobacz rysunek 1. 


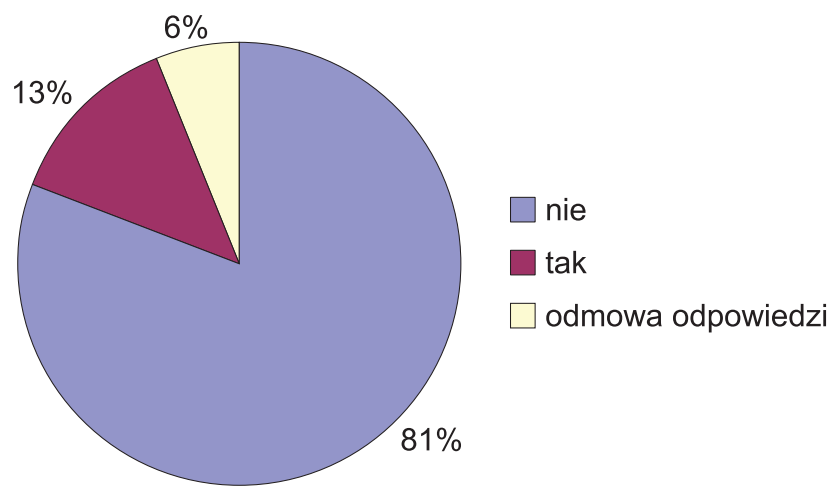

Wybór produktu:

\begin{tabular}{c|c|c|c|c|c}
\hline IKE & PSO & IKZE & PPE & $\begin{array}{c}\text { Odmowa } \\
\text { odpowiedzi }\end{array}$ & $\begin{array}{c}\text { Jeszcze } \\
\text { nie wiem }\end{array}$ \\
\hline $38 \%$ & $25 \%$ & $12 \%$ & $11 \%$ & $2 \%$ & $12 \%$ \\
\hline
\end{tabular}

Rysunek 1. Zamiar oszczędzania na emeryturę w jednym z oferowanych na polskim rynku produktów

Źródło: PWC 2013, s. 13.

Najwięcej osób badanych kojarzy IKE (63\%) ze słyszenia, lecz tylko 11\% deklaruje jego posiadanie. Pozostałe produkty, takie jak IKZE, PPE czy PSO, kojarzy mniej niż połowa badanych, a ich posiadanie deklaruje po 3\% respondentów. Najsłabiej znane są PPE, co można tłumaczyć tym, że IKE są na rynku najdłużej (14 lat). PPE są zbyt mało rozpowszechnione jako produkty emerytalne, niewiele osób o nich słyszało, gdyż nigdy nie było żadnych kampanii informacyjnych dotyczących tego produktu. Przyczyną braku ich popularności jest także po części konstrukcja PPE, do których można przystąpić tylko poprzez zakład pracy. Jeśli więc placówka nie zaoferuje pracownikowi PPE, istnieje nikła szansa, że o nim usłyszy. Warto też zwrócić uwagę na niewielki poziom wiedzy na temat produktów III filaru. Najistotniejszym czynnikiem, który mógłby skłonić do indywidualnego oszczędzania na emeryturę, jest posiadanie odpowiedniej ilości pieniędzy. Argument ten jest niezależny od statusu materialnego respondenta (Zalewska 2013).

\subsection{Zainteresowanie oszczędzaniem na emeryturę w ramach III filaru po zmianie roli OFE}

Z badania CBOS na temat „Wpływu reformy OFE na oszczędzanie w III filarze” wynika, że większość respondentów (60\%) urodzonych po 1948 roku nie zamierza oszczędzać na emeryturę w ramach III filaru nawet po istotnej zmianie roli OFE w systemie ubezpieczeń emerytalnych. Pewnych swych decyzji było $39 \%$ badanych. Zamiar takiego oszczędzania zadeklarowało 19\% badanych, z czego zdecydowanych było tylko 6\% (CBOS 2014, s. 2). Omawianą sytuację prezentuje rysunek 2. 


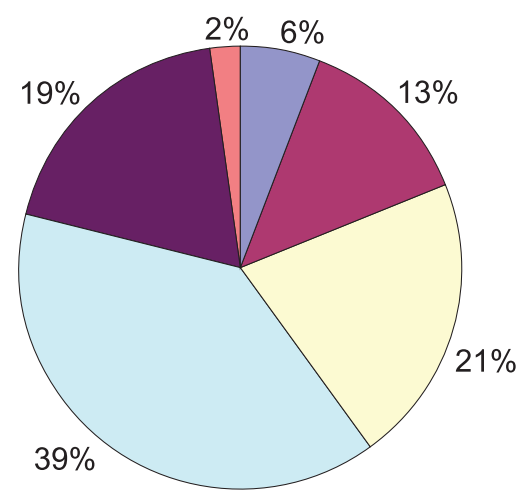

$$
\begin{aligned}
& \square \text { zdecydowanie tak } \\
& \square \text { raczej tak } \\
& \square \text { raczej nie } \\
& \square \text { zdecydowanie nie } \\
& \square \text { nie wiem jeszcze } \\
& \square \text { odmowa odpowiedzi }
\end{aligned}
$$

Rysunek 2. Liczba osób, które zamierzają oszczędzać na emeryturę w ramach III filaru na IKE lub IKZE po istotnej zmianie roli OFE w systemie ubezpieczeń emerytalnych (odpowiedzi osób urodzonych w latach 1949-1996)

\section{Źródło: CBOS 2014, s. 2.}

Z rzeczonych badań wynika, że zamiary respondentów związane z oszczędzaniem na emeryturę w ramach III filaru różnicuje przede wszystkim wiek. Jednak we wszystkich grupach wiekowych zamierzający dodatkowo oszczędzać na emeryturę stanowią mniejszość. Najczęściej zainteresowane taką formą oszczędzania są osoby poniżej 35 lat, z których ponad jedna czwarta deklaruje, że planuje oszczędzać. Z kolei w grupie wiekowej 18-24 lata 44\% respondentów nie podjęło jeszcze decyzji w kwestii oszczędzania, co jest związane z tym, że większość z nich nie ma jeszcze stałej pracy. Skłonność do oszczędzania na emeryturę maleje jednak wraz z wiekiem. W grupie wiekowej $45-54$ lata $73 \%$ nie jest nim zainteresowane, przy czym $47 \%$ jest pewna, że nie będzie oszczędzać w III filarze (CBOS 2014, s. 2-3).

Trzeba podkreślić - na co powinny zwrócić uwagę instytucje oferujące produkty III filaru - że decyzji odnośnie do wyboru konta nie podjęło jeszcze $66 \%$ respondentów chcących oszczędzać na emeryturę w III filarze. Wśród pozostałych znacznie większym zainteresowaniem cieszy się IKE (30\%) niż IKZE (8\%), przy czym w wypadku wyboru IKZE częściej wskazywano na równoczesne oszczędzanie w IKE (7\%) niż korzystanie jedynie z pierwszego rodzaju kont (1\%). Z kolei IKE z reguły wybierane jest jako jedyny produkt (23\%) (CBOS 2014, s. 5). Przedstawia to rysunek 3.

Należy zwrócić uwagę, że oszczędzaniem jednocześnie w IKE i IKZE zainteresowane są osoby $z$ wykształceniem wyższym i średnim. Ponadto zamiar oszczędzania w IKE deklaruje także co 10 badany absolwent zasadniczej szkoły zawodowej. Zamiar oszczędzania w IKZE deklarowały tylko osoby, których miesięczny dochód na jedną osobę w gospodarstwie domowym przekraczał $1000 \mathrm{zł}$. IKE jest produktem bardziej popularnym wśród osób o niższych dochodach per capita (CBOS 2014, s. 5). 


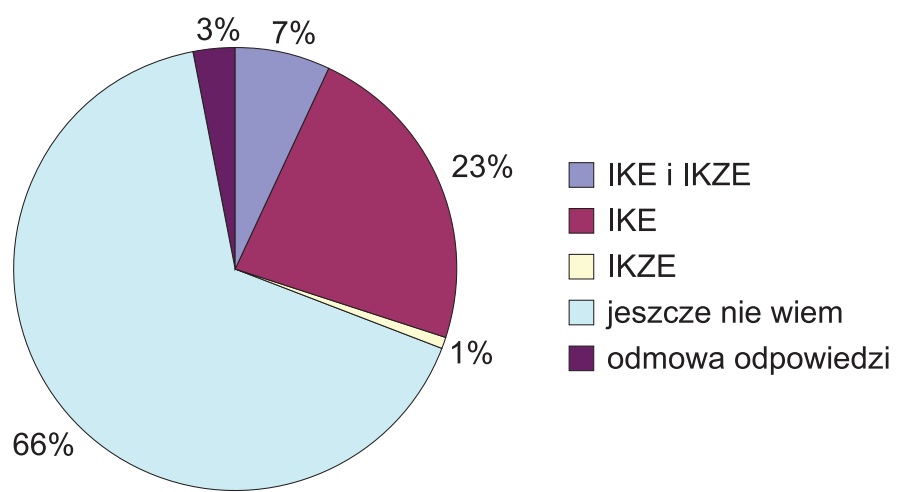

Rysunek 3. Najpopularniejsza forma oszczędzania w ramach III filaru (odpowiedzi osób urodzonych w latach 1949-1996 zamierzających oszczędzać na emeryturę w ramach III filaru na IKE lub IKZE)

Źródło: CBOS 2014, s. 5.

Z przeprowadzanych badań opinii publicznej można sformułować wniosek, że skłonność do dodatkowego oszczędzania na emeryturę jest marginalna. Z badań zrealizowanych przez Deutsche Bank PBC (2012) wynika, że osoby rozważające oszczędzanie oczekują możliwości skorzystania z produktów o bardzo elastycznych parametrach, głównie pod kątem wypłaty zgromadzonego kapitału.

\section{Opłacalność oszczędzania w III filarze}

Podstawową barierą rozwoju produktów oferowanych w ramach III filaru jest niski poziom wiedzy na ich temat oraz brak zachęt podatkowych. W dodatku biorąc pod uwagę obecną konstrukcję systemu emerytalnego, nie ma szans, aby ta forma cieszyła się popularnością. Główną barierą jest jednak kwestia świadomości społecznej potrzeby oszczędzania na przyszłą emeryturę.

W wypadku PPE, obok braku edukacji ekonomicznej, szczególne utrudnienie stanowi czas potrzebny na uzyskanie ich rejestracji w nadzorze. Proces negocjacji warunków ze związkami zawodowymi i zarządem może potrwać kilka miesięcy, kolejne kilka miesięcy trzeba będzie poczekać na rejestrację w KNF. Dodatkowo zmiany w PPE wymagają za każdym razem aneksu do umowy. Istniejące procedury zniechęcają firmy do tworzenia tych programów. Z kolei bez zachęt fiskalnych produkty z III filaru nie będą przyciągać zainteresowania.

Inaczej niż w Polsce przedstawia się sytuacja w krajach Europy Zachodniej, gdzie programy typu PPE działają w ramach II filaru, natomiast III filar tworza indywidualne plany emerytalne. Oszczędności w ramach PPE w Europie Zachodniej stanowią 60\%, w Holandii — 90\%, podczas gdy w Polsce lekko przekraczają 2\%. Opodatkowaniu w tych krajach podlega wyłącznie wypłata środków (w polskim systemie zarówno wpłata, jak i wypłata), w niektórych nie ma też po- 
datku od zysków kapitałowych, który obowiązuje w Polsce. Modyfikacja systemu podatkowego w naszym kraju jest koniecznym warunkiem, ale nie jedynym, aby ożywić ten rynek (Sondaż 2016).

IKE warto założyć, tylko jeśli: 1) szuka się systematycznego sposobu oszczędzania na dodatkową emeryturę; 2) pasuje nam któraś z sześciu form lokowania pieniędzy (lokata bankowa, obligacje skarbowe, fundusze inwestycyjne, dobrowolny fundusz inwestycyjny, rachunek maklerski, ubezpieczenie); 3) chcemy ochronić część oszczędności przed podatkiem od zysków kapitałowych.

W teorii IKE prezentuje się atrakcyjnie, jednak rzeczywistość wygląda inaczej — nie każde IKE jest dobrym i opłacalnym sposobem na sfinansowanie emerytury. W III filarze większość decyzji należy do konsumenta, co może być traktowane zarówno jako zaleta, jak i wada. Oferta wewnątrz III filaru jest zróżnicowana. Główną korzyścią IKE jest ulga podatkowa polegająca na zwolnieniu zgromadzonych oszczędności z podatku Belki (19\% zysku), jednak korzyść pojawi się tylko wówczas, gdy zostanie osiągnięty zysk w trakcie takiej inwestycji. Zakończenie inwestycji oddalone jest w czasie i zwłaszcza w wypadku wyboru ryzykownych sposobów lokowania kapitału (na przykład fundusze, rachunek maklerski) końcowy wynik jest niepewny. W wypadku oszczędzania na zbyt nisko oprocentowanej lokacie bankowej w formie IKE realny zysk może nie zostać wypracowany, gdyż odsetki będą rosły wolniej niż inflacja. IKE opłaca się, jedynie gdy korzysta się z „atrakcyjnych” możliwości oszczędzania na gwarantowany procent (przykładowo obligacji skarbowych uwzględniających inflację czy wysoko oprocentowanych lokat bankowych) albo wykorzystuje strategię inwestycyjną, mającą dać szansę na zarobienie w długim terminie. W tym wypadku im dłużej oszczędzamy i im wyższe wypracujemy średnioroczne zyski, tym większe są korzyści z ulgi podatkowej na koniec okresu oszczędzania (Sadowski 2013).

Barierą dla oszczędzenia w IKE może być również to, że inwestorzy chcieliby widzieć korzyść już dziś, a nie za 25 lat.

Banki oferują klientom IKE w formie rachunku oszczędnościowego. Jednak po obniżkach stóp procentowych przez NBP oprocentowanie ulokowanych tam pieniędzy przynosi marny zysk. Niskie oprocentowanie bankowego IKE jest główną przyczyną jego małej popularności. Przy niskim oprocentowaniu oferowanym przez banki oszczędności na przyszłą emeryturę nie ma sensu trzymanie pieniędzy na IKE w bankach. Zwłaszcza że tradycyjne konta oszczędnościowe mają oprocentowanie wyższe nawet o $2 \%$. Zysk z konta oszczędnościowego będzie zatem wyższy od tego z IKE nawet po zapłaceniu $19 \%$ podatku. Zysk z IKE jest zwolniony z podatku Belki, lecz tylko pod warunkiem, że pieniądze zostaną wypłacone, dopiero gdy osoba oszczędzająca osiągnie wiek emerytalny. Przy wcześniejszej wypłacie bank naliczy podatek od wypracowanego zysku (kapitał wraca w 100\%). Dodatkowym ograniczeniem w wypadku IKE jest roczny limit wpłat na konto (Boczoń 2016). 
Porównując oferty tych samych produktów finansowych w ramach IKE i w tradycyjnej formie, okazuje się, że większość banków daje lepsze oprocentowanie na zwykłych lokatach niż na lokatach IKE. Lokaty bankowe są znacznie lepszym produktem inwestycyjnym, umożliwiającym gromadzenie oszczędności na emeryturę, niż oferta proponowana w ramach III filaru z następujących powodów:

1. łatwo można je przedłużać - w momencie zakładania lokaty możemy zdecydować, czy lokata ma zostać odnowiona automatycznie, czy też pieniądze mają wrócić na konto. Można również poszukać oferty lokaty terminowej na kolejny okres w innym banku. W ten sposób pieniądze mogą być lokowane przez wiele lat. Warunkiem jest znajomość ofert rynkowych różnych banków;

2. proste i tanie - założenie oraz prowadzenie lokaty jest bezpłatne w przeciwieństwie do reklamowanych planów systematycznego oszczędzania, w których comiesięczne opłaty zmniejszają zyski, a także mogą powodować straty. W wypadku lokat, zwłaszcza w dłuższym czasie, brak kosztów jest istotny dla przyrostu oszczędności (lepiej działa procent składany). Niestety na jej zakończenie zapłacimy podatek od zysków kapitałowych;

3. bezpieczne - zgromadzone w bankach depozyty na lokatach objęte są BFG do wartości 100 tys. euro, a lokaty można mieć w różnych bankach. Lokaty bankowe są najbezpieczniejszą lokatą kapitału (Sadowski 2012).

Z kolei IKZE są produktem bardzo nieprzejrzystym dla statystycznego oszczędzającego. Korzyści z posiadania IKZE polegają na tym, że wypłaty z tego konta obecnie podlegają niższej, ryczałtowej stawce podatku w wysokości $10 \%$, oprócz tego składki można odliczyć od podstawy opodatkowania w zeznaniu rocznym, a ewentualne zyski ze środków tam zgromadzonych nie podlegają opodatkowaniu podatkiem Belki. $Z$ tych powodów IKZE wypada korzystniej w porównaniu z oszczędzaniem na zwykłych lokatach bankowych czy w funduszach inwestycyjnych poza III filarem, gdzie zgromadzonych oszczędności nie można odliczyć od podstawy opodatkowania w zeznaniu rocznym i w wypadku których istnieje obowiązek zapłacenia $19 \%$ podatku od zysków.

Ulga w podatku dochodowym na IKZE jest jednakże odsunięta w czasie do momentu osiągnięcia przez oszczędzającego wieku emerytalnego. Zatem należałoby zadać pytanie: jaki jest sens takiego oszczędzania, skoro oszczędzający (przyszły emeryt) musi czekać kilkanaście czy kilkadziesiąt lat, aby wypłacić oszczędności po preferencyjnej stawce podatkowej? Nie ma też pewności, że do tego momentu zasady oszczędzania na IKZE się nie zmienią — rząd może bowiem w każdym momencie zmienić warunki oszczędzania na IKZE na jego korzyść (jak ostatnio) lub niekorzyść. Funkcjonowanie produktów w ramach III filaru jest zatem kompletnie nieprzewidywalne (Sadowski 2014).

Ponadto w sytuacji kiedy w przyszłości oszczędzający będzie natychmiast potrzebował pieniędzy, może mieć na IKZE zgromadzonych tyle oszczędności, że ich zwrot spowoduje wejście w najwyższy próg podatkowy. Zwrot środków z IKZE podlega opodatkowaniu według obowiązującej skali podatkowej, a biorąc 
pod uwagę obecną politykę rządu, podatki w przyszłości będą raczej stale rosły, niż spadały. Zwrot środków z IKZE powiększa dochód w danym roku i istnieje duże niebezpieczeństwo konieczności zapłacenia części podatku po wyższej stawce. Wówczas IKZE będzie najkorzystniejszym źródłem lokowania środków (Sadowski 2014).

\section{Wnioski}

Reasumując, wybór zainteresowanego spośród produktów przeznaczonych na dodatkowe oszczędzanie na emeryturę jest uzależniony od indywidualnej sytuacji finansowej i preferencji odmiennych ulg i ułatwień dostępnych w ramach IKE, IKZE i PPE, to jest:

— zwolnienia zysków inwestycyjnych z tak zwanego podatku Belki (19\%), które odnosi się do wszystkich produktów;

— zwolnienia z podatku dochodowego w trakcie wypłaty środków w wypadku IKE;

- ulgi podatkowej oraz konieczności uiszczenia podatku dochodowego od uzyskanego dodatkowego przychodu przy wypłacie środków w przypadku IKZE;

- finansowania przez pracodawcę składki podstawowej oraz konieczności zapłacenia od niej podatku przez pracownika, co tyczy się PPE — możliwa składka dodatkowa $\mathrm{z}$ PPE finansowana jest przez pracownika $\mathrm{z}$ jego wynagrodzenia.

Należy wziąć także pod uwagę odmienne rozłożenie w czasie korzyści wynikających z konstrukcji poszczególnych produktów. W wypadku IKE oraz PPE ewentualne zalety widoczne są dopiero $\mathrm{w}$ momencie zakończenia inwestycji (podczas wypłaty środków), w wypadku IKZE — już na początku ze względu na możliwość skorzystania z ulgi podatkowej. Ponadto dzięki odliczeniom wpłat na IKZE od podatku inwestor ma do dyspozycji dodatkowy kapitał przez cały okres oszczędzania. Konieczność uiszczenia podatku dochodowego w wypadku IKZE jest „odroczona” w czasie, natomiast składki wpłacane na IKE i PPE nie obniżają podstawy opodatkowania oszczędzającego.

Wybór produktu z III filaru ma drugorzędne znaczenie, o wiele bardziej istotne jest regularne oszczędzanie, aby móc skorzystać z efektu tak zwanego procenta składanego, a także odpowiedni dobór strategii inwestycyjnej oraz skłonność do ryzyka. Najistotniejszymi elementami strategii inwestycyjnej jest:

- regularne wpłacanie podstawowych składek, a w zależności od konstrukcji wybranego produktu również składek dodatkowych, uzależnionych od dostępności nadwyżek finansowych;

- odpowiedni wybór profilu inwestycyjnego dostosowanego do wieku inwestora, wysokości wpłacanych składek, a także celu inwestycyjnego, który ma wpływ między innymi na decyzje dotyczące dywersyfikacji ryzyka inwestycyjnego. 
Przy wyborze produktu emerytalnego należy zwrócić szczególną uwagę na kwestię wysokości stałych opłat i dodatkowych kosztów związanych między innymi z zarządzaniem i wypłatą kapitału, gdyż produkty te są oferowane przez różne typy podmiotów i zastosowanie mają zróżnicowane polityki cenowe (PWC 2013).

Optymalne lokowanie czy gromadzenie oszczędności w III filarze łączy się też z wyłączną odpowiedzialnością właściciela konta za takie kwestie, jak na przykład unikanie nadmiernych kosztów, zbytniego ryzyka czy błędów inwestycyjnych. Z kolei większość społeczeństwa nie ma odpowiedniej wiedzy i umiejętności do oceny opłacalności inwestycji, a umowy produktowe są długie, często napisane niezrozumiałym językiem dla potencjalnego oszczędzającego.

Przeprowadzone badania potwierdzają, że nie nastąpiły zmiany w podejściu społeczeństwa do samodzielnego oszczędzania na emeryturę. Główną przeszkodą jest to, że większości społeczeństwa na nie zwyczajnie nie stać. Dość powszechne obawy budzi również rola państwa w III filarze. Obecnie strach przed oszczędzaniem w III filarze powoduje perspektywa przejęcia zgromadzonych w nim oszczędności przez państwo, podobnie jak oszczędności zgromadzonych w II filarze (OFE). W sytuacji przejęcia przez rząd Tuska ponad połowy oszczędności z OFE trudno, aby Polacy mieli zaufanie do systemu emerytalnego jako całości, podobnie jest $\mathrm{z}$ opodatkowaniem III filaru — w każdym momencie może ono zmienić się. Upowszechnienie III filaru jest możliwe tylko wówczas, gdy polski system emerytalny będzie stabilny i przewidywalny, reguły przejrzyste, a produkty proste i zrozumiałe (Zalewska 2016).

Społeczeństwo przede wszystkim powinno zrozumieć, na czym on polega, i mieć pewność, że wpłacone do niego środki nie zostaną przejęte przez kolejne zespoły rządzące oraz że oszczędzając na emeryturę, w przyszłości faktycznie będzie można otrzymać satysfakcjonujące świadczenia.

\section{Bibliografia}

III filar, http://emerytura.gov.pl/iii-filar/ (dostęp: 17.02.2016).

Boczoń W. (2015), Czy warto jeszcze trzymać pieniadze na bankowych IKE?, 22 sierpnia, http://www. bankier.pl/wiadomosc/Czy-warto-jeszcze-trzymac-pieniadze-na-bankowych-IKE-7274694. html (dostęp: 24.10.2016).

CBOS (2012), Jak Polacy planuja zabezpieczyć finansowo swoja przyszłość - czy zamierzaja w tym celu korzystać z IKZE?, Warszawa.

CBOS (2014), Wptyw reformy OFE na oszczędzanie w III filarze, Warszawa.

Deutsche Bank (2012), Czy Polacy zaczęli myśleć o emeryturze?, raport z badania Deutsche Bank PBC zrealizowanego przez Instytut Homo Homini, Warszawa.

Dygas M. (2014), Podrasowany III filar, „Gazeta Bankowa”, nr 4, s. 32-35.

IZFIA (2013), Raport z badania ,Polacy a ulga Podatkowa na IKZE”, Warszawa.

PWC (2013), Dodatkowe oszczędzanie na emeryturę w Polsce - perspektywa społeczna, Warszawa. Sadowski M. (2012), Jak oszczędzać na emeryturę — lokaty bankowe, 11 czerwca, http://www.mojaprzyszlaemerytura.pl/2012/06/jak-oszczedzac-na-emeryture-lokaty.html (dostęp: 24.10.2016). 
Sadowski M. (2013), Czy optaca się mieć IKE?, 8 lutego, http://www.mojaprzyszlaemerytura.pl/ 2013/02/czy-oplaca-sie-miec-ike-2013.html (dostęp: 24.10.2016).

Sadowski M. (2014), Jakie sa zasady IKZE po zmianach w 2014?, 2 lutego, http://www.mojaprzyszlaemerytura.pl/2014/02/zasady-ikze.html (dostęp: 24.10.2016).

Sondaż: Większość Polaków nie zna form oszczędzania na emeryturę w III filarze (2011), „Gazeta Prawna" 28.06, http://praca.gazetaprawna.pl/artykuly/526875,sondaz-wiekszosc-polakow-nie-zna-form-oszczedzania-na-emeryture-w-iii-filarze.html (dostęp: 20.02.2016).

UKNF: Urząd Komisji Nadzoru Finansowego (2013), Indywidualne konta emerytalne oraz indywidualne konta zabezpieczenia emerytalnego w 2012 roku, Warszawa.

UKNF: Urząd Komisji Nadzoru Finansowego (2014a), Indywidualne konta emerytalne oraz indywidualne konta zabezpieczenia emerytalnego w 2013 roku, Warszawa.

UKNF: Urząd Komisji Nadzoru Finansowego (2014b), Pracownicze Programy Emerytalne w 2013 roku, Warszawa.

UKNF: Urząd Komisji Nadzoru Finansowego (2015), Indywidualne konta emerytalne oraz indywidualne konta zabezpieczenia emerytalnego w 2014 roku, Warszawa.

UKNF: Urząd Komisji Nadzoru Finansowego (2016a), Indywidualne konta emerytalne oraz indywidualne konta zabezpieczenia emerytalnego w 2015 roku, Warszawa.

UKNF: Urząd Komisji Nadzoru Finansowego (2016b), Pracownicze Programy Emerytalne w 2015 roku, Warszawa.

Ustawa z dnia 22 sierpnia 1997 r. o pracowniczych programach emerytalnych, Dz.U. Nr 139, poz. 932.

Ustawa z dnia 20 kwietnia 2004 r. o indywidualnych kontach emerytalnych oraz indywidualnych kontach zabezpieczenia emerytalnego, Dz.U. Nr 116, poz. 1205.

Ustawa z dnia 20 kwietnia 2004 r. o pracowniczych programach emerytalnych, Dz.U. Nr 116, poz. 1207.

Ustawa z dnia 6 grudnia 2013 r. o zmianie niektórych ustaw w związku z określeniem zasad wypłaty emerytur ze środków zgromadzonych w otwartych funduszach emerytalnych, Dz.U. poz. 1717.

Zalewska A. (2013), Co mogłoby nas skłonić do dtugoterminowego oszczędzania?, 20 czerwca, https://www.analizy.pl/fundusze/wiadomosci/14676/co-mogloby-nas-sklonic-do-dlugoterminowego-oszczedzania.html (dostęp: 22.02.2016).

Ekonomia - Wroclaw Economic Review 23/3 (2017)

(C) for this edition by CNS 